\title{
Current Employment and Academic Status of Recent Dental Graduates in Dhaka City
}

\author{
Kabir FR ${ }^{1}$, Asaduzzaman $\mathrm{AKM}^{2}$, Aktar MT ${ }^{3}$, Islam $\mathrm{R}^{4}$, Kabir MF ${ }^{5}$, Samad MA ${ }^{6}$, Hasan MK ,
} $\operatorname{Mim} \mathrm{ZS}^{8}$

\begin{abstract}
This descriptive type of cross-sectional study was conducted with an objective to find out the present employment and academic status of recent dental graduates in Dhaka city. The study was conducted for one year from July 2019 to June 2020 at different work places of recent dental graduates and residence of unemployed dental graduates in Dhaka city. A total of 414 recent dental graduates were the respondents of the study.

Study revealed that $212(51.2 \%)$ of the respondents were male and $202(48.8 \%)$ of the respondents were female. With regards to employment, it was revealed that $340(82.1 \%)$ of the respondents were employed as dental surgeon and $57(13.8 \%)$ of the respondents were yet to get formal employment. Among the employed dental graduates, 203 (57\%) were full-time employee and 154 (47\%) were part-time. Only 55 (15.4\%) dental surgeons among them were working in government sector and rest were non-government employee or self-employed. Self-employment as a dental surgeon was the main source of income for 179 (43.2\%) of total respondents. Regarding the job satisfaction, $139(33.6 \%)$ were moderately satisfied and $182(44 \%)$ were not satisfied with their pay standard. With regards to further academic engagement, $88(21.2 \%)$ respondents were enrolled in different postgraduation courses whereas $205(49.5 \%)$ of the respondents were also engaged in learning activities to get admitted into postgraduation courses.

Study recommended that newly graduated dental surgeons could be utilized by engaging into both urban and rural areas by creating scope in both government and nongovernment sectors. Further academic engagement may be ensured by initiating new courses of dentistry and by increasing number of affiliated institutes for post-graduation.
\end{abstract}

Keywords: Current employment, Academic status, Dental graduates

1. Dr Fuad Reajwan Kabir, Assistant Professor (Dental Anatomy), Saphena Women's Dental College, Dhaka

2. Prof A K M Asaduzzaman, Professor (Community Medicine), Diabetic Association Medical College, Faridpur

3. Dr Muqbula Tasrin Aktar, Associate Professor (Pharmacology), NIO\&H, Dhaka

4. Brig Gen (Dr) Md. Rafiqul Islam, DMS (Army), Army Headquarters, Dhaka

5. Brig Gen (Dr) Md. Fazlul Kabir, Director, Mymensingh Medical College, Mymensingh

6. Brig Gen (Dr) Md. Abdus Samad, Adviser Anaestheologist, CMH, Dhaka

7. Brig Gen (Dr) M. Kumrul Hasan, Professor, Psychiatry, CMH, Dhaka

8. Dr Zakia Siddiqa Mim, Dental Surgeon, BSMMU, Dhaka

Address of correspondence: Fuad Reajwan Kabir, Assistant Professor, Dental Anatomy, Saphena Women's Dental College, Dhaka, email: fuad.kabir@outlook,com

\section{Introduction}

With the establishment of Dhaka Dental College in August 1961 undergraduate dental education started in Bangladesh and the first private dental college was established in 1995. According to DGHS data report 2014, there are 12 dental colleges and 23 dental units in the country out of which 26 are

Bangladesh Journal of Medical Education 2021; 12(2); Kabir FR et al., publisher and licensee Association for Medical Education Bangladesh. This is an Open Access article which permits unrestricted noncommercial use, provided the original work is properly cited. 
privately owned and only 9 are run by the government. ${ }^{11}$ This rise in dental colleges has led to a higher number of dental graduates. Similar pattern of growth has been reported in dental education from other countries such as India, Brazil, Columbia, Chile, Mexico, and Iran. ${ }^{14}$ Some of the consequences of this growth have been rising unemployment, low incomes and financial stress among graduates and a fall in the academic ranking of dentistry. The results of a cross-sectional survey conducted among FDI member nations published in 2012 report that many developing countries stated an oversupply of dentists. ${ }^{22}$ Despite such reports which indicate a scarcity of employment opportunities for dentists, many of these countries also reported the presence of underserved communities and areas in terms of oral health-care access, clearly indicating a situation of improper workforce planning. These consequences indicate that, the drastic growth of dental education in these settings, have also adversely impacted the professional circumstances of dentists. The gradual increase in the number of dental graduates is good for the overall oral health of the country, but growing number of dissatisfied dental graduates of because there are very low prospects of a job should be a matter of concern in respect of the future of dental profession and its public acceptance.

\section{Method}

This is a descriptive type of cross-sectional study (mixed method). The study was conducted during the period of July 2019 to June 2020 at different work places of recent dental graduates and residence of unemployed dental graduates in Dhaka city. The available and interested BMDC registered dental surgeons who has completed their BDS degree along with internship within last seven years were included in the study. Attempts were taken to collect quantitative data from 414 recent dental graduates from Dhaka city. The sampling technique used was convenient for the selection of the respondents for data collection and data collection sites were selected purposively. A self-administered semi-structured questionnaire were developed after pretesting to collect data from recent dental graduates. Written permission from the Director, CME was obtained before data collection. The study was carried after prior consent from the participants.

After checking and editing, data was analyzed by using SPSS computer software as per objectives of the study and presented by tables and graphs and necessary description for easy understanding and interpretation. Data which were derived from in-depth interview was scrutinized immediately after the meeting and summarized in a narrative.

Bangladesh Journal of Medical Education 2021; 12(2); Kabir FR et al., publisher and licensee Association for Medical Education Bangladesh. This is an Open Access article which permits unrestricted noncommercial use, provided the original work is properly cited. 


\section{Results}

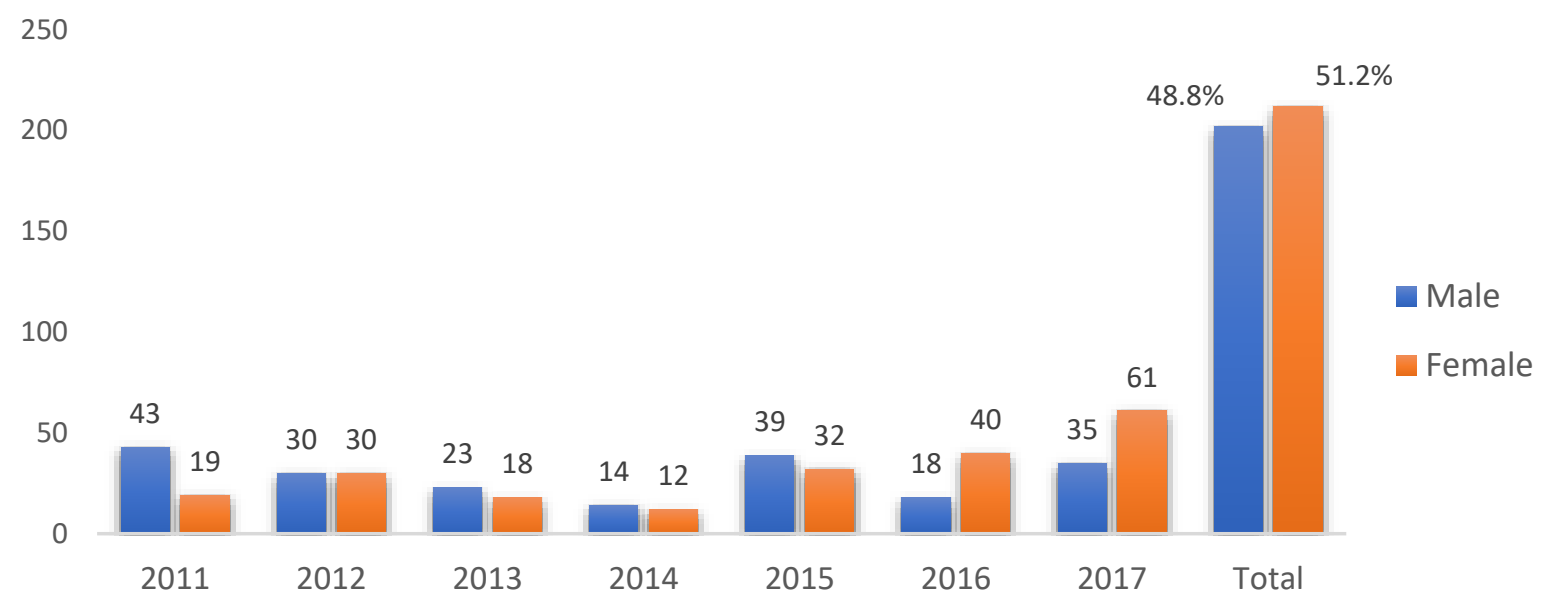

Figure I Distribution of recent dental graduates by their gender and passing year $(n=414)$

Table 1 Distribution of recent dental graduates having employment and employment as dental surgeon

\begin{tabular}{|c|c|c|c|}
\hline \multirow{2}{*}{$\begin{array}{c}\text { Employed as dental } \\
\text { surgeon }\end{array}$} & Yes & No & Total \\
\cline { 2 - 4 } & $340(82.1 \%)$ & --- & $340(82.1 \%)$ \\
\hline Yes & $17(4.1 \%)$ & $57(13.8 \%)$ & $74(17.9 \%)$ \\
\hline No & $357(86.2 \%)$ & $57(13.8 \%)$ & $414(100 \%)$ \\
\hline Total & & & \\
\hline
\end{tabular}

Table 2 Distribution of employed recent dental graduates by their types of service and place of employment $(n=357)$

\begin{tabular}{|c|c|c|c|c|c|}
\hline \multirow{2}{*}{$\begin{array}{c}\text { Types of } \\
\text { service as }\end{array}$} & Government & $\begin{array}{c}\text { Non- } \\
\text { government }\end{array}$ & $\begin{array}{c}\text { Military } \\
\text { service }\end{array}$ & $\begin{array}{c}\text { Self } \\
\text { employed }\end{array}$ & Total \\
\cline { 2 - 6 } Academician & 9 & 44 & --- & -- & 53 \\
\hline Clinician & 46 & 118 & 3 & 131 & 298 \\
\hline Researcher & --- & 2 & --- & --- & 2 \\
\hline Others & --- & 2 & -- & 2 & 4 \\
\hline Total & $55(15.4 \%)$ & $166(46.5 \%)$ & $3(0.8 \%)$ & $133(37.3 \%)$ & 357 \\
\hline
\end{tabular}

Bangladesh Journal of Medical Education 2021; 12(2); Kabir FR et al., publisher and licensee Association for Medical Education Bangladesh. This is an Open Access article which permits unrestricted noncommercial use, provided the original work is properly cited. 
Table 3: Distribution of recent dental surgeons based on factors related to employment and income $(n=414)$

\begin{tabular}{|c|c|c|c|c|c|c|}
\hline \multirow[b]{2}{*}{ Factor of satisfaction } & \multicolumn{5}{|c|}{ Level of satisfaction } & \multirow[b]{2}{*}{ Total } \\
\hline & $\begin{array}{l}\text { HDS } \\
\mathrm{f}(\%)\end{array}$ & $\begin{array}{l}\mathrm{DS} \\
\mathrm{f}(\%)\end{array}$ & $\begin{array}{l}\text { MS } \\
\mathrm{f}(\%)\end{array}$ & $\begin{array}{c}\mathrm{S} \\
\mathrm{f}(\%)\end{array}$ & $\begin{array}{l}\mathrm{HS} \\
\mathrm{f}(\%)\end{array}$ & \\
\hline $\begin{array}{l}\text { Satisfaction with } \\
\text { employment }\end{array}$ & $\begin{array}{c}38 \\
9.2 \%\end{array}$ & $\begin{array}{c}82 \\
19.8 \%\end{array}$ & $\begin{array}{c}151 \\
36.5 \%\end{array}$ & $\begin{array}{c}133 \\
32.1 \%\end{array}$ & $\begin{array}{c}10 \\
2.4 \%\end{array}$ & 414 \\
\hline $\begin{array}{l}\text { Pay standard of } \\
\text { employment }\end{array}$ & $\begin{array}{c}53 \\
12.8 \%\end{array}$ & $\begin{array}{c}129 \\
31.2 \%\end{array}$ & $\begin{array}{c}139 \\
33.6 \%\end{array}$ & $\begin{array}{c}91 \\
22 \%\end{array}$ & $\begin{array}{c}02 \\
0.5 \%\end{array}$ & 414 \\
\hline $\begin{array}{l}\text { Satisfaction with present } \\
\text { monthly income }\end{array}$ & $\begin{array}{c}47 \\
11.4 \%\end{array}$ & $\begin{array}{c}136 \\
32.9 \%\end{array}$ & $\begin{array}{c}95 \\
22.9 \%\end{array}$ & $\begin{array}{c}131 \\
31.6 \%\end{array}$ & $\begin{array}{c}05 \\
1.2 \%\end{array}$ & 414 \\
\hline
\end{tabular}

Legend: HDS = Highly dissatisfied, DS = Dissatisfied, MS = Moderately satisfied, $\mathrm{S}=$ Satisfied, $\mathrm{HS}=$ highly satisfied

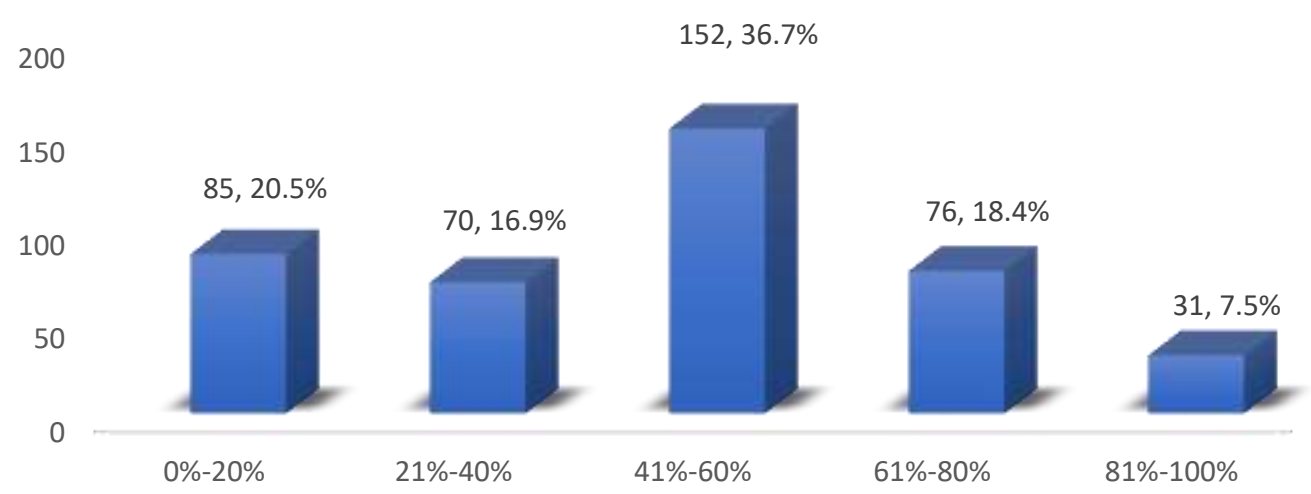

Figure 2 Opinion on approximate percentage of unemployed recent dental graduates

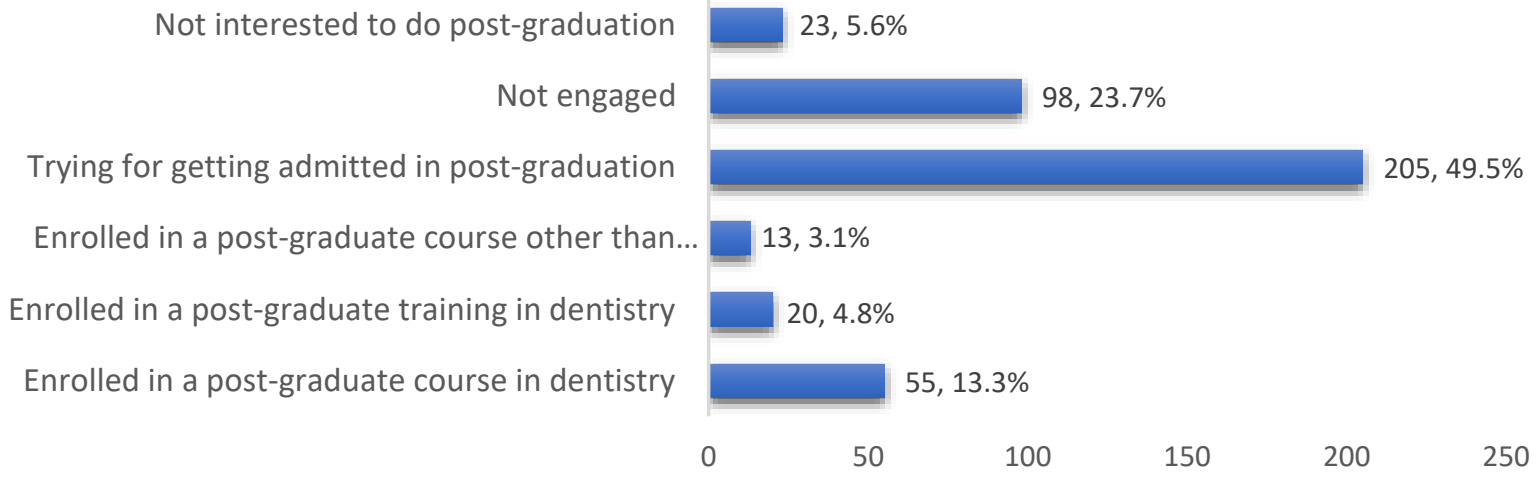

Figure 3 Present academic engagement of recent dental graduates after graduation

Bangladesh Journal of Medical Education 2021; 12(2); Kabir FR et al., publisher and licensee Association for Medical Education Bangladesh. This is an Open Access article which permits unrestricted noncommercial use, provided the original work is properly cited. 


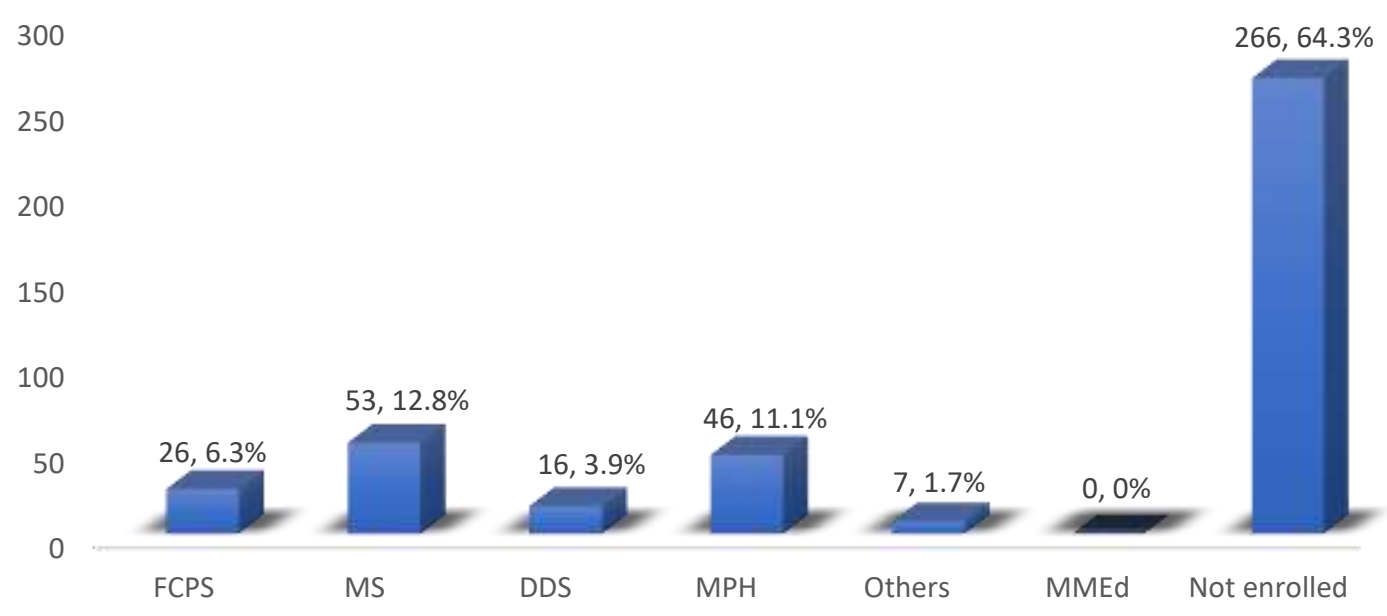

Figure 4 Name of enrolled postgraduation course

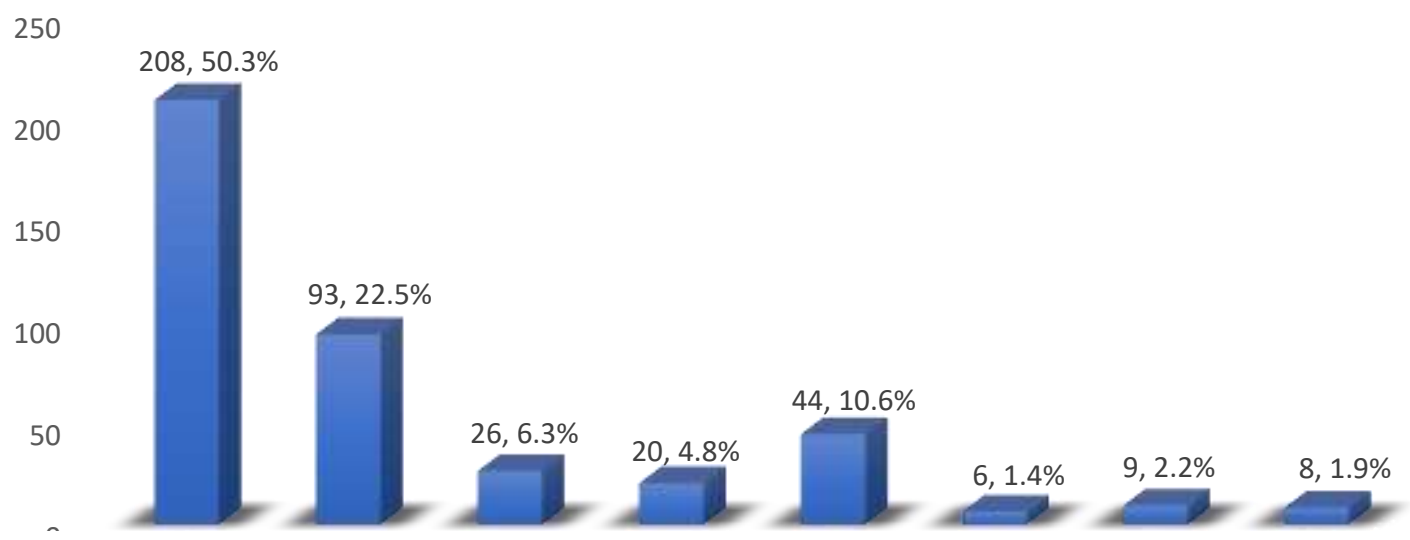

Figure 5 Opinion on approximate percentage of recent dental graduates enrolled in post-graduation courses

\section{Discussion}

In this study it was found that out of 414 recent dental graduates $86.2 \%$ were employed and most of them were employed as dental surgeon. Around $36.7 \%$ respondents also opined that $41-60 \%$ of their classmates were unemployed. A study in India shows that, the proportion of dental graduates employed (permanently or on contract basis) in the Kerala state public health sector is $<1 \%$, a making private dental practice sector, practically the sole Bangladesh Journal of Medical Education 2021; 12(2); Kabir FR et al., publisher and licensee Association for Medical Education Bangladesh. This is an Open Access article which permits unrestricted noncommercial use, provided the original work is properly cited. 
employment avenue for dentists. ${ }^{14}$ Very few numbers of posts are available for dentists in the government sector in India. Only 5\% graduated dentists are working in the government sector. ${ }^{5}$

In this study, $33.7 \%$ participants were selfemployed and nearly half of the recent dental graduates were working in non-government sector. Similar results found in the study in Philippines, where 41.67 percent of respondents were regular or permanent employees, followed by 29.17 percent were self-employed. ${ }^{8}$ Another study in Nepal shows, $79.37 \%$ professionally active dentists in Nepal were employed in private sector in private clinics/ hospitals, private medical/dental colleges and NGO's; and other $20.63 \%$ were working in government sector including government hospitals, law enforcing organizations and government medical/dental colleges. ${ }^{16}$ Majority of the graduates in India were currently engaged in various career options within dentistry whereas a significant proportion was also currently unemployed. ${ }^{2}$ Among the unemployed dental graduates, the majority reported that they were seeking employment, while others were seeking better employment opportunities than what was being offered to them. ${ }^{20}$

Another study reveals that, opening a private setup requires a healthy investment. The cost of equipment's and the locality of clinics need sound financial support. Even after such financial constraints the private practice is not easy due to already saturated market and competition. ${ }^{5}$
Satisfaction with the remuneration is one of the major dimensions contributing to job satisfaction among dentists reside in Australia. ${ }^{13}$ A study in India shows that $44 \%$ of the dental graduates were not satisfied with their income. An alarmingly high proportion of dentists who participated in the survey $(31 \%)$ expressed interest in changing their profession from dentistry. ${ }^{3}$

In this study, 32.4\% respondents also opined that among all recent dental graduates, approximately $0-5 \%$ of them were enrolled in post-graduation courses or completed postgraduation. Similar study in India shows that the total number of post-graduate seats available is only around 3000 compared to each year pass outs of 25000 dental graduates. ${ }^{7}$

\section{Conclusion}

The participants in this study gave their views regarding current employment and academic status of them. Almost all respondents responded positively towards different issues related to employment and further academic engagement in dentistry and showed their affection and passion towards dental profession and professional responsibility which holds much promise to ensure safety of oral and dental health of people of Bangladesh. The responses from the participants in the study provided some suggestion about raise of employment opportunities and scope of post-graduation.

Base on the study findings, following recommendations are made:

Bangladesh Journal of Medical Education 2021; 12(2); Kabir FR et al., publisher and licensee Association for Medical Education Bangladesh. This is an Open Access article which permits unrestricted noncommercial use, provided the original work is properly cited. 
- Newly graduated dental surgeons could be engaged in both urban and rural areas to decentralize dental health services.

- Employment opportunity could be raised to create new scope in both government and private sector including NG organizations.

- Well defined job description and standardization of remuneration should be established in the private job sector to improve job satisfaction among the recent dental graduates.

- Scope of post-graduation needed to be raised by initiating new courses in basic, para-clinical and clinical dental subjects.

- Number of affiliated dental institutes for post-graduation should be raised to meet the demand of further academic engagement of recent dental graduates.

\section{Reference}

1. Acheampong AO, Ampofo P, Newman-Nartey M, 2018. PostGraduate Dental Education: The Ghanaian Experience. Dentistry, an open access journal 8: 490. doi:10.4172/2161-1122.1000490.

2. Ashish K, Jaiswal, Srinivas $P$ and Suresh S, 2014. Dental manpower in India: changing trends since 1920. International Dental Journal; 64: 213-218

3. Bhagwani H, Mishra SK, Yadav NS, 2017. Choosing dentistry as a career a matter of concern a survey. $\mathrm{N}$ Niger
Journal of Clinical Research; 6:1620.

4. Cartes-Velásquez RA, 2013. Exponential growth of dental schools in Chile: Effects on academic, economic and workforce issues. Brazilian Oral Research Journal; 27:471-7

5. Dagli N, Dagli R, 2015, Increasing Unemployment among Indian Dental Graduates - High Time to Control Dental Manpower. Journal of International Oral Health; 7(3):i-ii. PubMed

6. History of Dhaka Dental College. http://www.dhakadental.gov.bd/

7. Jain H, Agarwal A., 2012. Current scenario and crisis facing dental college graduates in India. Journal of Clinical and Diagnostic Research. 2012; 3824:1892.

8. Jennifer D. Maderazo., 2016. Tracer Study of Dentistry Graduates of one Higher Education Institution in the Philippines from 2008 to 2012. Asia Pacific Journal of Multidisciplinary Research, Vol. 4 No.3, 160 - 167

9. Jones K, Teusner D, 2005. Job satisfaction of registered dental practitioners. Australian Dental Journal 2005;50:(3):179-185.

10. Kathryn A. Atchison, Carol A. Bibb, Karen H. Lefever, Ronald S. Mito, 2002. Gender Differences in Career and Practice Patterns of PGDTrained Dentists. Journal of Dental Education, Volume 66, No. 12

11. List of dental colleges and available seats from Directorate General of

Bangladesh Journal of Medical Education 2021; 12(2); Kabir FR et al., publisher and licensee Association for Medical Education Bangladesh. This is an Open Access article which permits unrestricted noncommercial use, provided the original work is properly cited. 
Health Services (DGHS) data report 2014.

http://www.dghs.gov.bd/images/doc s/Admission/Govt.MC_Dental_and_ Private_MC_Dental_College_2.pdf

12. List of Recognized Medical \& Dental Colleges and Dental Units (Govt. \& Non-Govt.). Bangladesh Medical and Dental Council (BMDC). https://web.bmdc.org.bd/aboutcollege-n.

13. Luzzi L, Spencer AJ, 2011. Job satisfaction of the oral health labour force in Australia. Aust Dent J 2011; 56:23-32.

14. Mohan M, Sundari Ravindran TK, 2018. Unemployment and vulnerable financial situation among recent dental graduates of Kerala, India Results from a cross-sectional study. J Global Oral Health 2018;1(1):4957.

15. Puryer J, Selby J, Layton J, Sandy J and Ireland A, 2017, The association between postgraduate studies, gender and qualifying dental school for graduates qualifying from UK dental schools between 2000 and 2009 . Dent. J, 5, 11; doi:10.3390/dj5010011.

16. Rosales L \& Sanchez L, 2008, Tracer study for the Dentistry graduates SY 1990-2007: Basis for a Proposed Enhanced Program. Lyceum of the Philippines University College Journal.
17. Roth K, 2007. Dental Education: A Leadership Challenge for Dental Educators and Practitioners. Journal of Dental Education, Volume 71, Number 8.

18. Schwartz B, Bhan A, 2005, Professionalism and challenges in dental education in India. Indian Journal of Medical Ethics OctoberDecember; 2(4):119-21.

19. Shrestha RM, Shrestha S, Kunwar N, 2017, Dentists in Nepal: A Situation Analysis. J Nepal Health Res Counc, May - Aug;15(36): 187-92.

20. Siddiqui Z, Srivastava R, Kohli V, 2018, The future prospects of dental graduates in India: A review. International Journal of Contemporary Medicine Surgery and Radiology; 3: B156-60. DOI: 10.21276/ijcmsr.2018.3.2.37

21. Yadav S\& Rawal G, 2016. The current status of dental graduates in India. Pan African Medical Journal; 23:22 doi:10.11604.

22. Yamalik N, Ensaldo-Carrasco E, Cavalle E, Kell K., 2014. Oral health workforce planning Part 2: Figures, determinants and trends in a sample of world dental federation member countries. Int Dent J; 64:117-26.

Bangladesh Journal of Medical Education 2021; 12(2); Kabir FR et al., publisher and licensee Association for Medical Education Bangladesh. This is an Open Access article which permits unrestricted noncommercial use, provided the original work is properly cited. 